\title{
The Influence of Perceived Value on Customer Loyalty in Slovenian Hotel Industry
}

Tadeja Krasna*

\section{Abstract}

Perceived value has an enormous influence on customer behaviour, because it influences his decisions on product choice, purchase intentions and repeat purchasing. Most frequently it appears in connection with quality and customer satisfaction. The purpose of this article is to present the role of perceived values as marketing tool for assuring customer loyalty in Slovenian hotel industry, where knowing a guest and understanding his wishes and expectations plays an essential part. By means of qualitative marketing research it was ascertained that the offer of Slovenian hoteliers does not differ in general from the offer of other hoteliers; this is why they are trying to expose characteristics which are most appreciated by guests. They are laying great emphasis on culinary art, creation of homelike feeling and integrated experience. Key words: perceived value, loyalty, hotel industry

\section{Introduction}

In recent years it has been recognised that consumer behaviour is better understood when analysed through perceived value. In fact, value is a key for gaining competitive advantage (Woodroof, 1997; Day, 1999). Therefore it is essential for hotel managers to be able to compare specific business practices in terms of their relative contributions to creating value and ultimately, customer loyalty. Managers also have to be able to pinpoint which of the hotel attributes are most critical in the creation of customer value.

\section{Value concept of customer behaviour}

The concept of value is old and endemic to consumer behaviour. It could be said that the value concept has been constantly revisited by consumer and marketing researchers. In the tourism literature Oh (200o) proposes that: "By offering new insights into consumer behaviour surroundings price-quality trade offs, customer value may unveil deep-seated driving forces of purchase decision and brand loyalty."

* Višja strokovna šola za gostinstvo in turizem Bled, Slovenija; tadeja.krasna@guest.arnes.si 
The consumer value concept has evolved from the development of two pivotal dimensions of consumer behaviour: the economic (value is linked to perceived prices) and psychological (what does really influence the product choice: emotional aspects) (Gallaraza, Saura, 2004). The most universally accepted definition of perceived value is conceptual proposal by Zeithaml (1988) - the overall assessment of the utility of a product based on the perceptions on what is received and what is given. Sheth et al. (1991) identify four dimensions: emotional value, social value, and two types of functional value (price/value for money and performance/quality). Holbrook (1999) considers eight separate categories of consumer value: efficiency, excellence (quality), play, aesthetics, esteem, status, ethics and spirituality.

The value construct can help explain different areas of consumer behaviour: product choice, purchase intention and repeat purchasing. Value is very often related to customer loyalty (Parasurman, Grewal, 2000). As Neal (1999) said, value predicts choice, thus loyalty. Buyers who are considering a purchase in a particular product or service category scan their product/service options and develop a consideration set. Within the consideration set, they develop a hierarchy of products based on their assessment of value. They can choose the product at the top of their value hierarchy, if available. This may be a conscious, cognitive process or a subconscious process with some emotional elements. If one can accurately measure a purchaser's relative value structure for product or service category, then one can accurately predict that purchaser's choice among a set of competing products/services or brands in that category (Neal, 1999).

Dubé and Reneghan (1999) tried to find out which hotel attributes are the most important for creating the value. They found that functional areas that generate high loyalty scores are: the quality of the various on-site hotel services, the quality of personnel, the quality of guest room design and amenities, a strong brand name and positive reputation and perceived value. Dubé et al. (1999) also established that a discrepancy exists between what guests desire and managers pursue, therein lies a strategic opportunity for improving operations and maximizing profit.

\section{The relation between service quality and guests behavioural intentions}

A qualitative research was made in Slovenian hotels to identify the link between service quality, satisfaction and behavioural intentions. Eleven in-depth interviews were given by hotel managers. The pattern was intentional - it includes managers of different types and categories of hotels from different geographical areas. By means of the interviews I wanted to find out what significance is given to quality, satisfaction and loyalty behaviour by hoteliers, what, in their opinion, most contributes to loyalty behaviour, and where they point their market efforts for its assurance.

Managers' answers to the question why guests return were different. Mostly they mentioned two reasons, the location of a hotel and relation towards a guest. Location was mentioned in leisure as well as in commercial hotels. In leisure hotels and spa resorts they particularly linked location with gifts of nature, pleasant and peaceful environment, however, in commercial hotels managers mainly emphasised the meaning of hotel accessibility. Some of them stated that they do not differ essentially from competition, and do not find that to be a problem; therefore they started to lay more emphasis on relations with guests. They are aware of the fact that they have to differ somehow from competition. The majority of them found out that these differences do not exist or are very small in the eyes of guests; this is why they started searching for possibilities to do away with this deficiency. They see a solution in relation 
towards a guest and personal approach to a guest, where personnel have the main role, because guests frequently return just on the account of them. The location is important, but personnel are more significant - guests know them and trust them to a certain level.

A guest has to feel comfortable in a hotel; therefore many hoteliers mentioned "the soul of the hotel". If you ask managers, what is "the soul of the hotel", they mainly use expressions like "atmosphere", "charm", "pleasant rooms", "equipment", "warm colours", "details", "attentiveness", "friendly relations" etc. They were mentioning both tangible and intangible elements, with which they assure a certain value to guests. They put a lot of energy in the creation of homelike feeling, because they have noticed that this matters much to guests. Some of them stated that guests are more and more individually oriented and they do not socialize much with one another or they do not establish interactions, this is why they have to try harder to fulfil their time with various activities. Managers think that slight attentiveness means a lot to guests, where the fact of knowing them plays a big role. Guests like it if you know them by name and surname. But this is not as simple as one might think, in practice this can be very complicated, especially if it is a guest's first stay in a hotel and a porter has to greet him by name and surname. This means that a hotel must have a good system of information and informing. Impression on the guest is in such case extremely strong, because a guest has to have a feeling that personnel are interested in his needs, wants and feelings. From his/her point of view it is important that he/she does not need to explain over and over again what he/she wants. In a hotel, personnel have to learn continuously what a customer needs and expects in order to react properly and establish good interactions. Genuine relation with a guest represents a competitive advantage for a hotel, and is hard to imitate.

Staying in a hotel must be an emotional experience for a guest, and it has to be based on positive experiences. Emotions are in accordance with theoretical cognitions, one of those elements that create customer value and influence on guest loyalty. Probability that an emotionally attached guest would change a hotel is essentially smaller, but for now hoteliers do not deal with studying guests' feelings and do not use them as a marketing tool. However, some managers mentioned feeling of satisfaction, possibility of relaxation, kindness, genuineness, prestige and spoiling. These are also reasons that were mentioned for guests' return to a hotel.

One of the reasons why guests return is also a combination of offered services, if possible included in a package that is customized. Guests can get everything in one place and they do not need to search for other offers, leave a hotel and pay certain services additionally. Even though the hoteliers are making their best for a guest to use as many services as possible in a hotel, they cooperate with local communities in connection with organization of events, because a guest is not only interested in staying in a hotel but also in the surroundings, what he can do or see in that environment. Food offer also belongs to the most significant tourist activities, because tourists often wish to eat outside the establishment in which they are staying. Managers are aware of this fact; this is why they are laying a great emphasis on culinary art. Besides culinary offer, adjusted to individual target groups of guests, they frequently open their own restaurants into which they send their guests. They see a marketing opportunity in culinary offer of this kind. Culinary art is certainly one of the motivation reasons when choosing a destination and also a reason to return to a destination as well as into a hotel.

Only one of the participants referred to good price policy. Others think that price approach is somehow out-of-date, and they already let that know when answering the question about loyalty rewards. They do not believe that discounts represent an important marketing tool, especially when loyal guests, who are less touchy about prices, are concerned. They give it sym- 
bolically and in cases for which they estimate that it is beneficial. More and more significant are: strong brand, knowing guests, services adjusted to individuals etc.

Among reasons why guests return to a hotel the participants frequently mentioned that a guest has to receive certain value in return for his money, he has to know in advance what he will get for his money. In the majority of cases they linked value with quality, which is seen as one of the most important loyalty factors.

\section{Conclusion}

For hotel operation it is very important to define properly customer value, because perceived value is crucial for customers to return and their recommendation of services to friends, relatives and others. Service characteristics are very significant, because every customer perceives them in his own way, therefore it is very difficult to define value. Factors that influence on customer's evaluation of perceived value are several, for example, service characteristics, price, marketing brand, quality, perceived effort for gaining services and other higher factors. Above all, value is connected with customer overall experience when using a product or a service. This experience should be also overall emotional experience, which is worth remembering. Therefore a hotel must, if it wants offer appropriate services to a customer, find out customer's wants and needs. A special emphasis has to be given on value delivery, where customer and employer are in interaction. Interaction between a customer and employer is one of the crucial moments for creating satisfaction and at the same time establishing loyalty. The fact that customers are more and more demanding and that sometimes slight attention means a lot to them also has to be taken into consideration.

\section{References}

Day, G. S. (1999): Market driven strategy. Process of creating value (2nd ed.). New York: The Free Press.

Dubé, L., Renaghan, L. M. (1999): Building customer loyalty - Part I. Cornell Hotel and Restaurant Administration Quarterly, 40(5), 78-88.

Gallarza, M. G., Saura, I. G. (2006): Value dimensions, perceived value, satisfaction and loyalty: an investigation of university students' travel behaviour. Tourism management, 27, 437452.

Holbrook, M. B. (1999): Customer value. A framework for analysis and research. London: Routlledge.

Neal, D. W. (1999): Satisfaction is nice, but value drives loyalty. Marketing Research, 21-23.

Oh, H. (2000): The effect of brand class, brand awareness, and price on customer value and behavioural intentions. Journal of hospitality and Tourism Research, 24(2), 136-162.

Parasuraman, A., Grewal, D. (200o): The impact of technology on the quality-value-loyalty chain: a research agenda. Journal of the Academy of Marketing Science, 28(1), 168-174.

Sheth, J. N., Newman, B. I., \& Gross, B. L. (1991): Why we buy what we buy: a theory of consumption values. Journal of Business research, 22, 159-170.

Woodruff, B. R. (1997): Customer value: the next source for competitive advantage. Journal of the Academy of Marketing Science, 25(2), 139-153. 